\title{
Brasília e a invenção da arquitetura-arte: transformações estéticas na noção espacial da obra de arte
}

\author{
Márcio Takeo Sobral Hagihara \\ Orientador: Doutor João Gabriel Lima Cruz Teixeira \\ Tese de Doutorado \\ Data da defesa: 19.07.2011
}

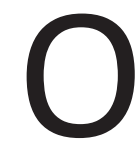

advento das instalações e de obras que visam à interação com o público, criando ambientes que envolvem percepções sinestésicas, estão presentes nas mais célebres bienais e exposições de arte pelo mundo. A arquitetura e a arte brasileiras contribuíram bastante para a mudança espacial da obra de arte. O modernismo brasileiro forjou o discurso de ampliação dos princípios das artes plásticas para a construção da cultura nacional. A dimensão construtiva das artes plásticas refletiu-se na ampliação da criação plástica dos singelos quadros de cavalete burgueses para os murais sociais de Portinari e para a nacional e monumental arquitetura do Grupo Carioca. Oscar Niemeyer e Lucio Costa projetaram a pretensão máxima de ampliação de escala da obra de arte: Brasília. Frustrada a utopia, irrompe o Movimento Neoconcreto, cuja crítica infligiu-se contra a arquitetura, o espaço clássico e o conceito de cultura nacional, por meio da quebra da tradicional associação simbólica entre arte e cultura. A ligação entre a arquitetura e o Movimento Neoconcreto só faz sentido se ligada à análise iconográfica, pois o exame do discurso escrito - que é uma das obsessões de nossa cultura pela palavra - é insuficiente para estabelecer tal ligação. Entre maquetes e instalações labirínticas de Hélio Oiticica, observa-se a crítica visual da coerência espacial imposta pela política cultural das elites brasileiras. Mais do que isso, a arte brasileira deu sua contribuição, modificando a configuração espacial da obra de arte. Foi preciso destruir a última grande regra da arte, através da morte do Plano.

Palavras-chave: Sociologia da Arte, Arquitetura-arte, Brasília, Grupo Carioca, Oscar Niemeyer, Lucio Costa, Artes Plásticas, Hélio Oiticica, Movimento Neoconcreto, Instalação. 